\title{
USING STABLE ISOTOPES TO DISTINGUISH SINKHOLE AND DIFFUSE STORM INFILTRATION IN TWO ADJACENT SPRINGS
}

James L. Berglund

Dept. of Earth and Environmental Science, Temple University, Philadelphia, Pennsylvania, 19122, USA, james.berglund@temple.edu

Laura Toran

Dept. of Earth and Environmental Science, Temple University, Philadelphia, Pennsylvania, 19122, USA, ltoran@temple.edu

Ellen K. Herman

Dept. of Geology, Bucknell University, Lewisburg, Pennsylvania, 17837, USA, ekh008@bucknell.edu

\section{Abstract}

Two karst springs, Tippery Spring and Near Tippery Spring, have similar discharges $\left(\sim 0.1 \mathrm{~m}^{3} / \mathrm{s}, 5 \mathrm{cfs}\right)$ and are only 30 meters apart, yet they show unique behaviors in terms of water chemistry and discharge response to storms. Near Tippery has higher $\mathrm{Mg} / \mathrm{Ca}$ ratio and Tippery Spring has more variable temperature response to storm events. This contrast was further extended to differences in recharge pathways based on stable isotope analysis $\left(\delta \mathrm{D} \& \delta^{18} \mathrm{O}\right)$ of spring water samples collected using ISCO automated samplers during a May $(3 \mathrm{~cm}$, 1 inch) storm and June (8 cm, 3 inch) storm in 2017.

Increased spring discharge preceded the arrival of storm water as conduits were purged of pre-storm water, indicated by no change in isotopic composition on the rising limb. The isotopic signature then became progressively more enriched at both springs, indicating storm water recharge. At Tippery, this enrichment began around peak flow, sooner than at Near Tippery where enrichment began during the descending limb. Thus, isotopes indicated a stronger surface connection at Tippery. Storm water recharge at both springs then progressed to a greater relative fraction of total discharge before recovering to pre-storm values within 24-36 hours. Storm intensity also affected the relative contribution of recharging water reaching both springs, with the June storm producing a larger recharge signature compared to the May storm. At Tippery, for a short time the majority of emerging water is storm water, with the absolute pre-storm contribution falling below its baseflow value. This reduction in pre-storm water may indicate a reversal in water exchange between the conduits and the surrounding matrix, an important consideration in karst contaminant transport.
While both springs can be traced to sinks, their isotopic signatures reflect how storm water infiltrates and travels within each spring's recharge area. Tippery is fed by a perennial sinking stream and more developed conduit network, while Near Tippery has a more diffuse recharge area with mixing of different surface inputs. As stable isotopes are unaffected by redox or dissolution processes, they can provide a conservative tracer with which to characterize how other parameters, such as temperature, alkalinity, and turbidity, are reflected in different spring recharge behaviors.

\section{Introduction Background}

Water emerging from a karst spring is a mixture of different sourced waters within its recharge area and along the flow path (Ford \& Williams, 1989). When surface connections are strong and travel times are short, spring water composition will be variable in response to recharge events. Since recharging water interacts with the surrounding rock as it travels along conduits, temperature can be used as a reactive tracer providing information about karst structure and recharge characteristics (Covington et al., 2011; Luhmann et al., 2011). Different thermal patterns develop as a result of the effectiveness of heat exchange between water and rock between a spring and its recharge area. When the surface temperature signature is preserved at the spring mouth, heat exchange is thermally ineffective, indicating rapid recharge, short flow paths, or large conduits. In contrast, springs with constant temperatures show thermally effective heat exchange, indicating more diffuse recharge, slow groundwater flow, and longer flow paths. 
When stable isotope compositions of the recharge and waters along the flow path are distinctly different, then a hydrograph separation can be performed through an end-member mixing analysis. In the simplest two endmember scenario, spring water can be divided into prestorm water and storm water (Lakey \& Krothe, 1996; Fredrickson and Criss, 1999). As real systems may be a mix of more than two sources, such as perched epikarst water (Perrin et al., 2003; Aquilina et al., 2005), three and four component scenarios have also been also been explored (Lee \& Krothe, 2001). Thus, both geochemical and thermal signatures of water at a spring reveal information about recharge sources and the travel path.

This study aims to contribute to the growing body of karst isotope hydrology through a comparison of isotopic storm responses between two adjacent springs. Because the adjacent springs receive recharge of the same isotopic composition, the resulting differences in isotope hydrographs are used to contrast recharge and flow paths. Not only can the flow paths feeding the springs be compared, but also contrasted from storm to storm due to antecedent moisture and rainfall intensity differences. Furthermore, the timing of the surface water component based on isotopes relative to other constituents (dissolved ions, sediment) provides insights into flow path length and mixing.

\section{Study Site}

Tippery Spring and Near Tippery Spring emanate from folded Ordovician dolomite (Berg, 1980). Due to topography and folding, several formations are exposed within each spring's estimated recharge area, transitioning uphill to limestone, shale, and then sandstone. Four local sinkholes occur near the contact between the shale and limestone, roughly half a mile to the northwest of the springs. Three of the sinkholes have been traced to Tippery Spring, while the remaining sinkhole has been traced to Near Tippery Spring (Hull, 1980). The two springs are at an elevation of $270 \mathrm{~m}$ (900 feet) MSL, and the sinkhole elevations are from 304-324 m (1000-1030 feet) MSL, with total relief of $400 \mathrm{~m}$ (1300 feet) within the springs' estimated recharge areas.

Of the three sinkholes traced to Tippery Spring, one is fed by a perennial stream which completely submerges at the sink, referred to here as Tippery Sink. The sinkhole traced to Near Tippery Spring does not have an associated perennial stream. Based on the dye traces, no crossover flow was apparent between each spring's delineated recharge area as each sinkhole traces to just one spring or the other. Although both springs emerge from the dolomite, the flow path between Tippery Spring and its three associated sinkholes is largely within the limestone unit, while Near Tippery Spring's flow path is within both the limestone and the dolomite (Figure 1).

Tippery Spring and Near Tippery Spring are less than 30 meters apart and emerge at similar baseflow discharge $\left(\sim 0.1 \mathrm{~m}^{3} / \mathrm{s} ; 5 \mathrm{cfs}\right)$, but show historical differences in seasonal water chemistry, such as slightly greater seasonal variation in temperature at Tippery Spring (Figure 2) and a higher $\mathrm{Mg} / \mathrm{Ca}$ ratio in Near Tippery Spring (Shuster \& White, 1971). More recent research with high-resolution discharge monitoring has further explained these behavioral differences (Herman et al., 2009).

Expanding on the observed seasonal temperature behavior of the two springs is more recently observed behavioral differences in temperature response after a storm (Figure 3). Tippery Spring tends to have a flashier thermal response, while Near Tippery Spring's response

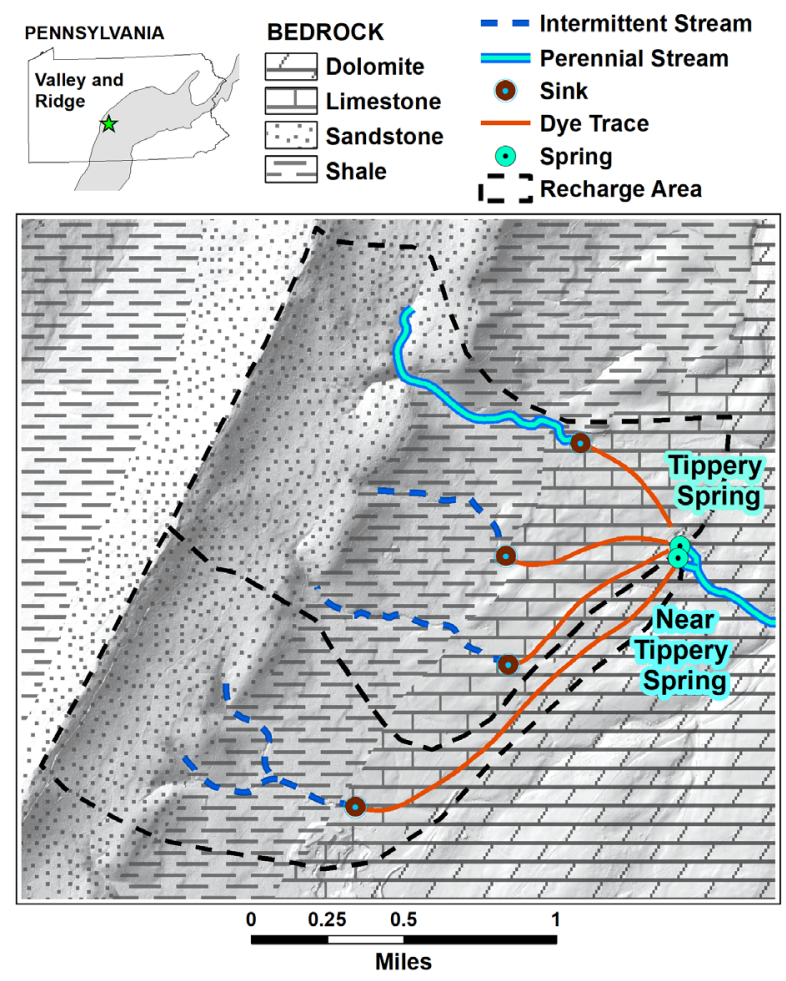

Figure 1. Location of Tippery Spring and Near Tippery Spring. Geology and hydrography data from Pennsylvania Spatial Data Access (PASDA). 

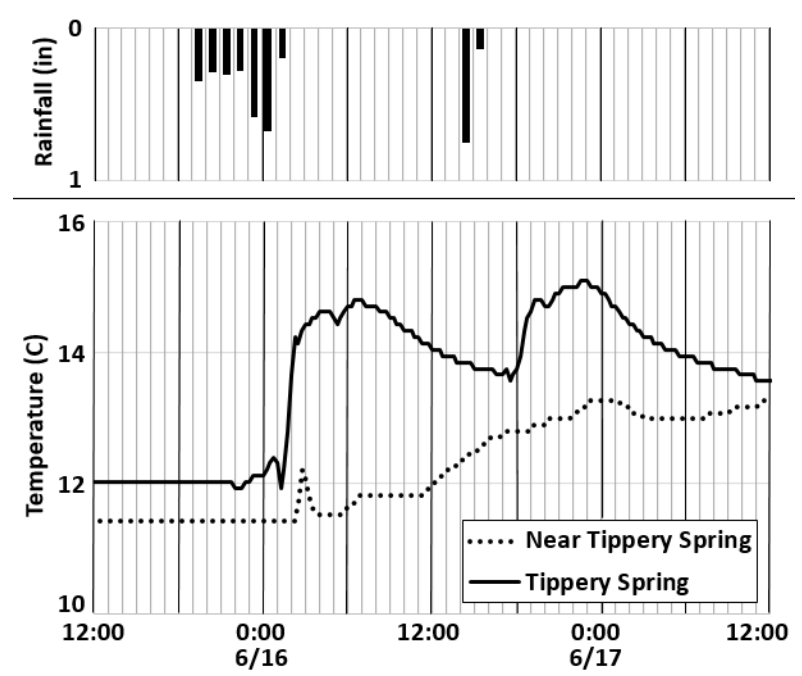

Figure 2. Seasonal temperature patterns from bi-weekly sampling for Tippery Spring and Near Tippery Spring, after Shuster \& White (1971). While both springs show seasonal variation, indicating surface influence, Tippery Spring more closely follows seasonal extremes, indicating a greater degree of surface influence.

is more delayed and buffered. As Tippery Spring and Near Tippery Spring's recharge areas receive rainfall simultaneously from the same events, these thermal variations can be attributed to differences in the springs' surface connectivity and conduit geometry. For Tippery Spring, this suggests a stronger surface connection and a well-developed conduit network between surface and spring. For Near Tippery Spring, this suggests a dampened surface connection and greater water-rock interaction due to the greater degree of thermal diffusion.

These behavioral differences provide an opportunity to further assess the use of stable isotope variations for karst springs. While temperature variations suggest differences in recharge behavior between the two springs, variations in isotopic composition can further quantify these differences as they act as conservative tracers to study the timing and contribution of the isotopically distinct water sources. For Tippery Spring, this would be represented with a more dominant storm water signal. For Near Tippery Spring, this would be represented with a more buffered storm water signal.

\section{Methods}

Water samples were collected as grab samples during field visits and with ISCO 3700 auto-samplers triggered from rising spring water level in response to storms. The ISCO auto-samplers fill 24, 1-liter, acid-washed bottles over the course of 24 hours, beginning with a high sampling frequency (every half hour) followed by decreasing frequency (every 2 hours). Bottles were retrieved within 12 hours after the storm ended, filtered with $0.45 \mu \mathrm{m}$ nitrocellulose paper, and refrigerated in headspace-free bottles.

Spring water level and temperature were recorded with Onset HOBO pressure loggers at 15-minute intervals. Pressure was converted to water depth and corrected for logger placement, resulting in water depth of the pool at the mouth of each spring. Local precipitation data was recorded using a $\mathrm{HOBO}$ rain gauge data logger. $\mathrm{pH}$ was recorded using Manta2 data loggers at 15-minute intervals and during field visits with an IQ Scientific Instruments IQ150 meter with a Thermo Scientific Orion 9106BNWP pH electrode.

Samples were analyzed for ${ }^{18} \mathrm{O} /{ }^{16} \mathrm{O}$ and $\mathrm{D} / \mathrm{H}$ isotope ratios using a Laser Water Isotope Analyzer V2 (Los Gatos Research, Inc., Mountain View, CA, USA at the UC Davis isotope laboratory) and reported relative to Vienna Standard Mean Ocean Water (VSMOW). These values are reported in delta $(\delta)$ notation in parts per thousand (permil) such that

$$
\delta\left({ }^{18} O, D\right)=\left(\frac{R_{M}-R_{V S M O W}}{R_{V S M O W}}\right) \times 1000
$$

where $R_{M}$ is the ratio of ${ }^{18} \mathrm{O} /{ }^{16} \mathrm{O}$ or $\mathrm{D} / \mathrm{H}$ in the water sample $R_{\text {VSMOW }}$ is the ratio of ${ }^{18} \mathrm{O} /{ }^{16} \mathrm{O}$ or $\mathrm{D} / \mathrm{H}$ in the VSMOW standard.

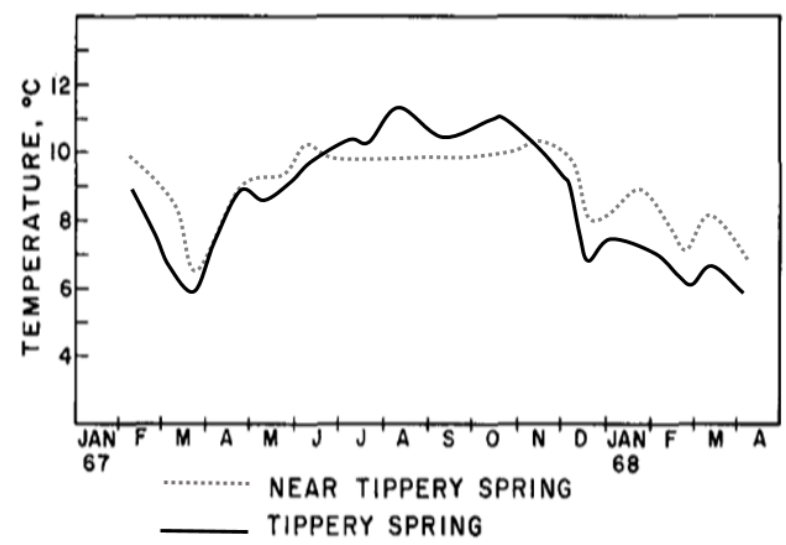

Figure 3. Temperature response at Tippery Spring and Near Tippery Spring in response to a June 2017 storm as part of this study. Vertical grid has a one-hour minor interval and six-hour major interval. Note the flashier response of Tippery Spring relative to Near Tippery Spring, indicative of a stronger surface connection. 
Stable isotope data for rainwater were available for 2009-2011 from the nearby Shale Hills Critical Zone Observatory approximately $25 \mathrm{~km}$ from the springs (Duffy and Thomas, 2011). Precipitation was collected from the ridge top in the SHCZO using an event triggered sampler and analyzed at Penn State University.

Additional parameters, such as turbidity, total dissolved solids (TDS), and alkalinity were also measured to interpret the arrival of storm pulses. Turbidity was estimated using digital photometry as samples stored in transparent bottles showed visible turbidity pulses in response to the storms. Sample bottles were photographed while the sediment was suspended, converted to grayscale images, and the relative luminosity was measured digitally (Figure 4). TDS was calculated from ion concentrations measured with a Thermo Scientific iCAP 7200 inductively coupled plasma optical emission spectrometry (ICP-OES) analyzer and a Dionex ion chromatography (IC) analyzer and checked against specific conductance measured with an Extech Instruments 407313 conductivity meter. Alkalinity was measured with a Hanna Instruments HI 775 alkalinity colorimeter.

\section{Sampled Storm Events 1-inch Storm (May 4-7, 2017)}

A 1-inch storm lasting 7 hours fell on the study site on May 4, 2017 (Figure 5). Preceding this storm, water level was $27 \mathrm{~cm}$ at Tippery Spring and $21 \mathrm{~cm}$ at Near Tippery Spring, slightly elevated compared to their annual average values of $18 \mathrm{~cm}$ and $15 \mathrm{~cm}$, respectively. Two days prior, the site experienced a slight drizzle $(1 \mathrm{~cm}$, $<0.5$ inch). Slightly wet antecedent conditions prevailed, resulting in the initially elevated flow conditions, although water level was essentially stable at the time.

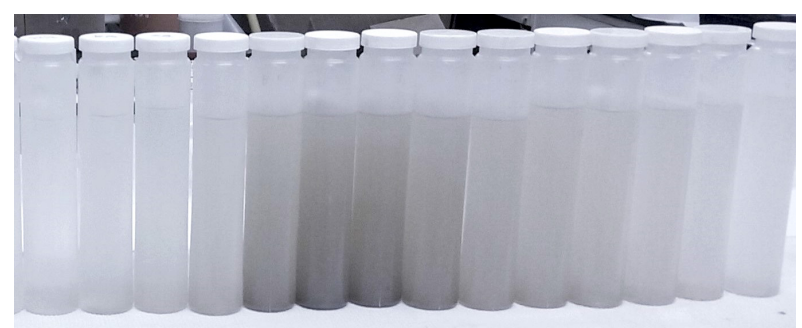

Figure 4. Visual turbidity change in Tippery Spring water samples capturing the storm pulse as it reached the spring. Increased turbidity resulted in darker bottles and therefore a lower pixel luminosity. Shown: May storm samples from 5/5/17 6:00-20:00.

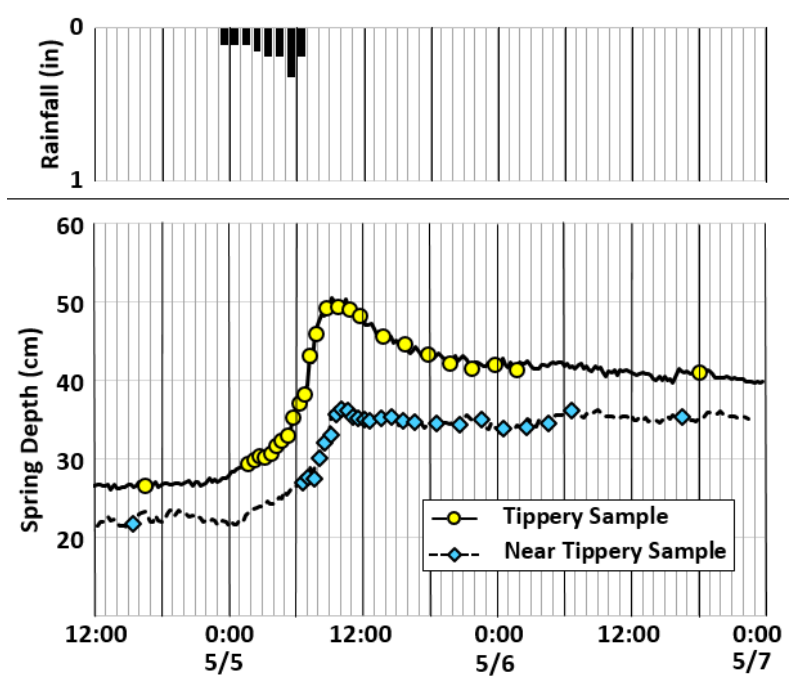

Figure 5. Rainfall, storm hydrograph, and sampling times for Tippery Spring and Near Tippery Spring, May 4-7, 2017. Vertical grid has a one-hour minor interval and six-hour major interval.

Grab samples were collected from both springs and the Tippery Sink 9 hours before the start of rainfall on May 4 , 2017. The ISCO auto-samplers were activated at Tippery Spring and Near Tippery Spring 3 and 7 hours after the start of rainfall, respectively. Both ISCOs collected 24 samples across the rising limb, peak, and falling limb (Figure 5). Follow-up grab samples were collected at the springs about 12 hours after the end of the 24-hour ISCO sampling period.

\section{3-inch Storm (June 14-17, 2017)}

A 3-inch storm began to fall on the study site on June 14, 2017. This rainfall was divided in two pulses; the initial rainfall on June 14, which totaled two inches over 7 hours, and a second, smaller 1-inch pulse on June 15, which lasted for 2 hours. Both rainfall pulses resulted in distinct water level responses at both springs. Preceding rainfall, water level was $20 \mathrm{~cm}$ at Tippery Spring and $15 \mathrm{~cm}$ at Near Tippery Spring. These levels were similar to their average annual values of $18 \mathrm{~cm}$ and $15 \mathrm{~cm}$, respectively. No rainfall events had occurred within two weeks prior. Dry antecedent conditions prevailed, resulting in the initially low flow conditions.

Grab samples were collected at each spring and Tippery Sink both 9 and 11 days before rainfall. The ISCO autosamplers were activated at Tippery Spring and Near Tippery Spring 4 hours and 6 hours after the start of rainfall, respectively. Both auto-samplers collected a 
total of 24 samples across the rising limbs, peaks, and descending limbs of both storm pulses (Figure 6).

\section{Results}

\section{Samples vs. Local Meteoric Water Line}

From 2008-2012, local springtime precipitation isotopic composition varied from $-100 \%$ to $7 \%$ o $\delta$ with a volume-weighted mean of $-26.1 \%$ o $\delta$, and $\delta^{18} \mathrm{O}$ varied from $-11 \%$ to $1 \%$ o $\delta^{18} \mathrm{O}$ with a volume-weighted mean of $-4.5 \%$ o $\delta^{18} \mathrm{O}$. Pre-storm (baseflow) isotopic values, determined from pre-storm influence samples, were similar between both springs and for both storms, at $-54.61 \pm 1.22 \%$ o $\delta$ and $-8.62 \pm 0.36 \%{ }^{18} \mathrm{O}$, which were similar to the volume-weighted annual means of precipitation values of $-57.35 \%$ o $\delta \mathrm{D}$ and $-8.71 \%$ $\delta^{18} \mathrm{O}$ at the Shale Hills CZO (Figure 7). In response to the May storm, Tippery and Near Tippery's isotopic compositions were temporarily perturbed to maximum values of $-49.54 \%$ o $\delta \mathrm{D} \&-7.64 \%$ o $\delta^{18} \mathrm{O}$, and $-49.19 \%$ $\delta \mathrm{D} \&-7.98 \%$ o $\delta^{18} \mathrm{O}$, respectively, before returning to baseflow values. Following the June storm, Tippery and Near Tippery's compositions were temporarily perturbed to maximum values of $-36.52 \% 0 \mathrm{D} \&-6.52 \% \mathrm{~d}^{18} \mathrm{O}$, and $-39.87 \%$ o $\delta \mathrm{D} \&-6.72 \%$ o $\delta^{18} \mathrm{O}$, respectively. All spring samples from the storm events plotted near the weighted Local Mean Water Line (Figure 7). Since the isotopic compositions of pre-storm and storm water differed but followed a mixing line, a binary mixing analysis, along with spring depth, allowed for characterization of the

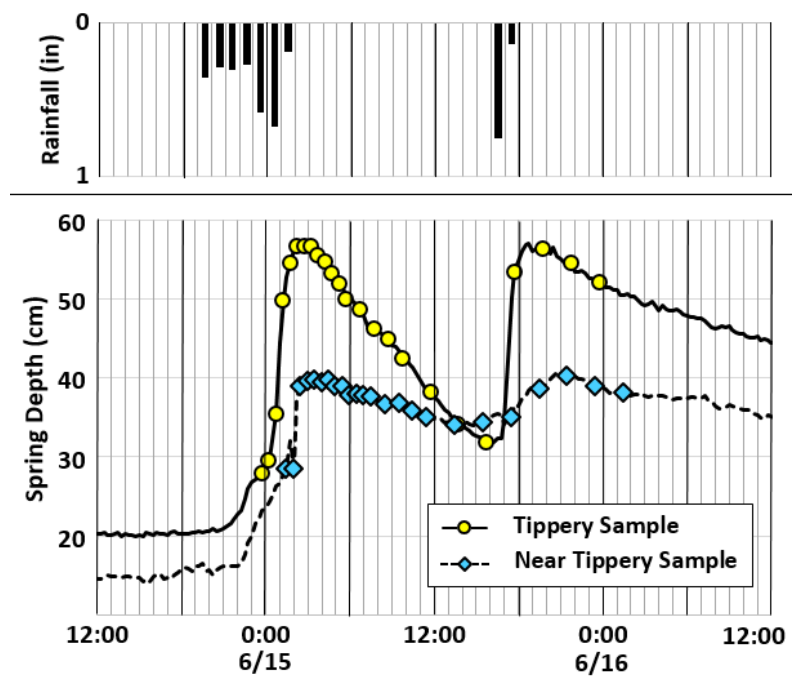

Figure 6. Rainfall, storm hydrograph and sampling times for Tippery Spring and Near Tippery Spring, June 14-17, 2017. Vertical grid has a one-hour minor interval and six-hour major interval. timing and relative contribution of each component emerging from the springs.

\section{Hydrograph Separation}

Assuming a two end-member mixing model, storm water in the pre-storm water components can be separated as a binary mixing model

$$
Q_{R}=Q_{M} \frac{\left(\delta_{M}-\delta_{P S}\right)}{\left(\delta_{R}-\delta_{P S}\right)}
$$

where $Q_{R}$ is the fraction of discharge which is storm water, $Q_{M}$ is the discharge at the time of sample, $\delta_{M}$ is the measured isotopic composition of spring water, $\delta_{P S}$ is the isotopic composition of pre-storm spring water, and $\delta_{R}$ is the isotopic composition of the storm water. Prestorm spring water $\left(\delta_{P S}\right)$ values were determined from baseflow samples prior to storm response. Storm water values $\left(\delta_{R}\right)$ were based on average values for spring precipitation (Duffy and Thomas, 2011). A summary of isotopic values is provided in Table 1 .

Applying Equation (2) to the measured isotopic composition and spring depth for each sample results in a storm hydrograph, showing the relative contributions of pre-storm water and storm water throughout the hydrograph. As direct discharge values were not

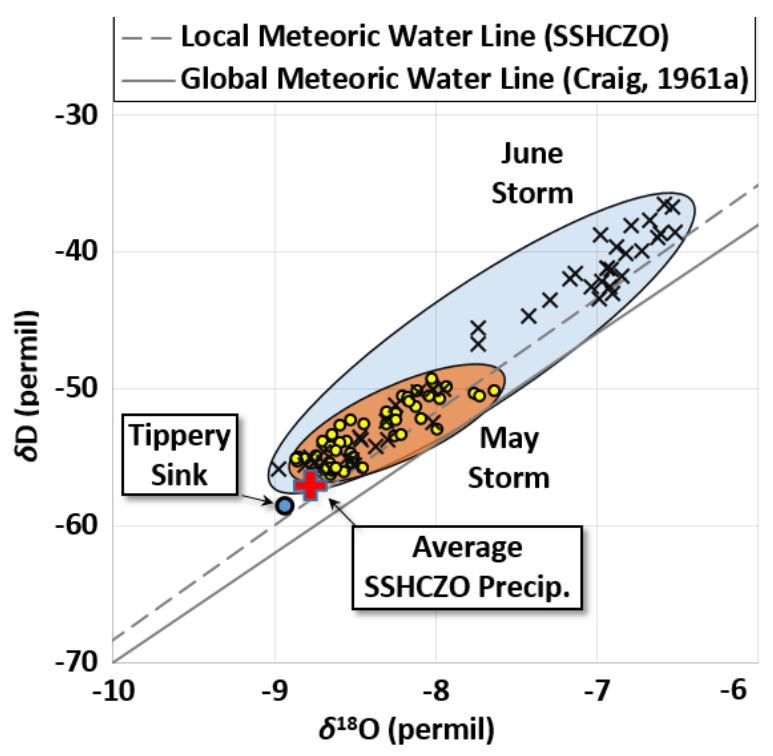

Figure 7. Storm sample isotopic composition. May ( 1 -inch) storm values (yellow circles) highlighted overall by the orange oval. June (3-inch) storm values (black X's) highlighted by the blue oval. Unique symbols for each spring were not plotted due to the strong overlap in values. 


\begin{tabular}{|c|c|c|c|}
\hline Source & Parameter & $\delta D \%$ & $\delta^{18} \mathrm{O} \%$ \\
\hline $\begin{array}{c}\text { SHCZO } \\
(2008-2012)\end{array}$ & Mean Spring Precipitation $\left(\delta \_R\right)$ & -26.10 & -5.50 \\
\hline \multirow{4}{*}{$\begin{array}{c}\text { May } 2017 \\
\text { Storm (1-inch) }\end{array}$} & Tippery Spring, pre-storm ( $\delta \_P S$ ) & -55.00 & -8.80 \\
\hline & Tippery Spring, maximum response & -49.54 & -7.64 \\
\hline & Near Tippery Spring, pre-storm ( $\left.\delta \_P S\right)$ & -55.00 & -8.54 \\
\hline & Near Tippery Spring, maximum response & -49.19 & -7.98 \\
\hline \multirow{4}{*}{$\begin{array}{c}\text { June } 2017 \\
\text { Storm (3-inch) }\end{array}$} & Tippery Spring, pre-storm ( $\delta \_P S$ ) & -55.00 & -8.80 \\
\hline & Tippery Spring, maximum response & -36.52 & -6.52 \\
\hline & Near Tippery Spring, pre-storm ( $\left.\delta \_P S\right)$ & -53.50 & -8.55 \\
\hline & Near Tippery Spring, maximum response & -39.88 & -6.72 \\
\hline
\end{tabular}

Table 1. Summary of isotopic values.

obtained for each spring, water level at the spring mouth was used instead. Given that an average storm isotope composition was used, rather than actual storm values, there is some uncertainty in the calculations. The range in seasonal isotopic composition suggests about 5\% uncertainty for the May storm and $10 \%$ for the June storm due to a higher storm water component.

\section{May (1-inch) Storm Hydrographs}

Tippery Spring's water level began to rise 2 hours after the start of rainfall, from $27 \mathrm{~cm}$ to $50 \mathrm{~cm}$ over the course of 9 hours (Figure 8). Isotopic composition of spring water showed no significant change throughout the rising limb, with the first indication of storm water arriving just before peak flow. Relative contribution of storm water increased during the descending limb, reaching a maximum component of $20 \%$. This component then decreased, returning to $0 \%$ 24-32 hours after sampling began and 26 hours after the start of rainfall. This isotopic recovery occurred despite the lack of water level recovery to pre-storm levels.

Near Tippery Spring's water level started to rise 3 hours after rainfall began (Figure 9). Water level rose gradually from $21 \mathrm{~cm}$ to $35 \mathrm{~cm}$ over the course of 9 hours. Spring water isotopic composition first showed indications of mixing just after peak flow and lasting for several hours. Spring water at this time was more depleted in $\delta \mathrm{D}$ and $\delta^{18} \mathrm{O}$ relative to pre-storm water, despite the storm water being more enriched. Spring water composition eventually shifted towards enrichment 6 hours after peak flow, indicating the arrival of storm water, which increased progressively to a relative component of $10 \%$ around 12 hours after peak flow. The storm water component then decreased to near pre-storm levels by the collection of the grab sample 10 hours after the last ISCO sample was collected. Despite the isotopic composition returning to near pre-storm values during
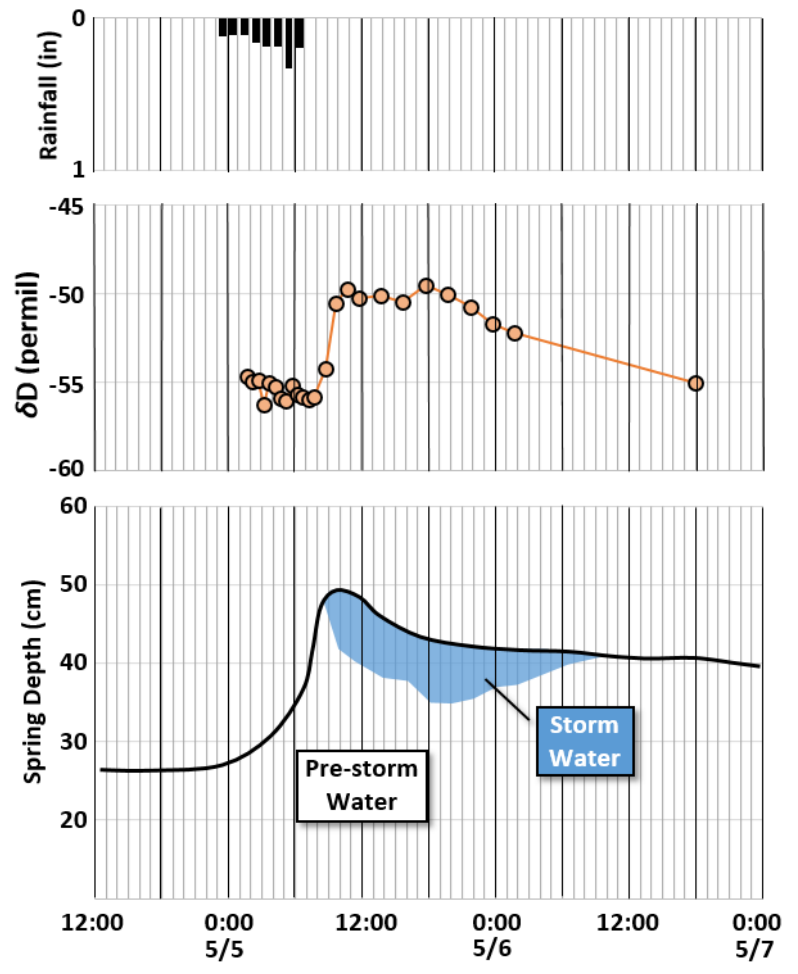

Figure 8. Tippery Spring, May (1-inch) Storm, rainfall, $\delta D$ values, and spring hydrograph with pre-storm and storm water separation. Vertical grid has a one-hour minor interval and six-hour major interval.

the May storm at Tippery Spring, spring water level did not return to pre-storm levels, which was the case for both springs during both storms.

\section{June (3-inch) Storm Hydrographs}

Tippery Spring's water level began to rise 2 hours after rainfall began, rising sharply from $20 \mathrm{~cm}$ to $57 \mathrm{~cm}$ over the course of 6 hours (Figure 10). Similar to the May storm, spring water showed no significant isotopic change throughout the rising limb, with the first indication of storm water arriving just before peak flow. Relative contribution of storm water then increased during the descending limb, reaching a maximum relative component of over $60 \%$ halfway through the descending limb. Before water level and isotopic composition could recover to pre-storm levels, the second storm pulse arrived, raising water level and again increasing the relative contribution of storm water. Full recovery was not observed before the end of the 24-hour water sampling period.

Near Tippery Spring's water level began to rise 4 hours after the start of rainfall. Water level rose from $14 \mathrm{~cm}$ 

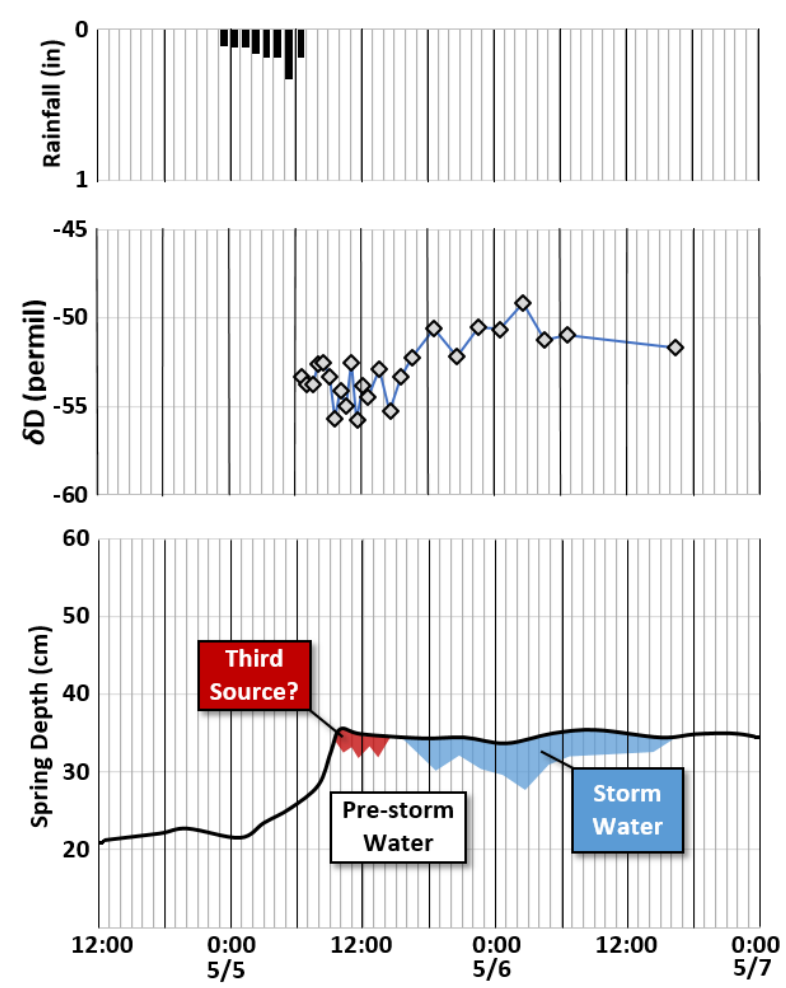

Figure 9. Near Tippery Spring, May (1inch) Storm, rainfall, $\delta D$ values, and spring hydrograph with pre-storm and storm water separation. Vertical grid has a one-hour minor interval and six-hour major interval.

to $40 \mathrm{~cm}$ over the course of 8 hours (Figure 11). Spring water isotopic composition first indicated mixing with a depleted isotope signal which lasted for 2-3 hours during peak flow before returning to an unmixed signal. This short-lived mixing signature shared a similar timing as the May storm, although it showed an isotopic depletion during the May storm and isotopic enrichment during the June storm.

As spring water level began dropping, the storm water signal appeared, increasing gradually to a $53 \%$ relative component 14 hours after peak flow. Around this time, the second rainfall pulse occurred and, although this raised the water level again (from $34 \mathrm{~cm}$ to $40 \mathrm{~cm}$ ), there was no change in isotopic composition for the remainder of sampling. Neither water level nor isotopic composition recovered by the end of the 24-hour sampling period.

\section{Additional Parameters}

In addition to stable isotopes, water samples were also analyzed for TDS and alkalinity along with visual turbidity changes. Although each spring showed notable changes to these parameters in response to storms, the
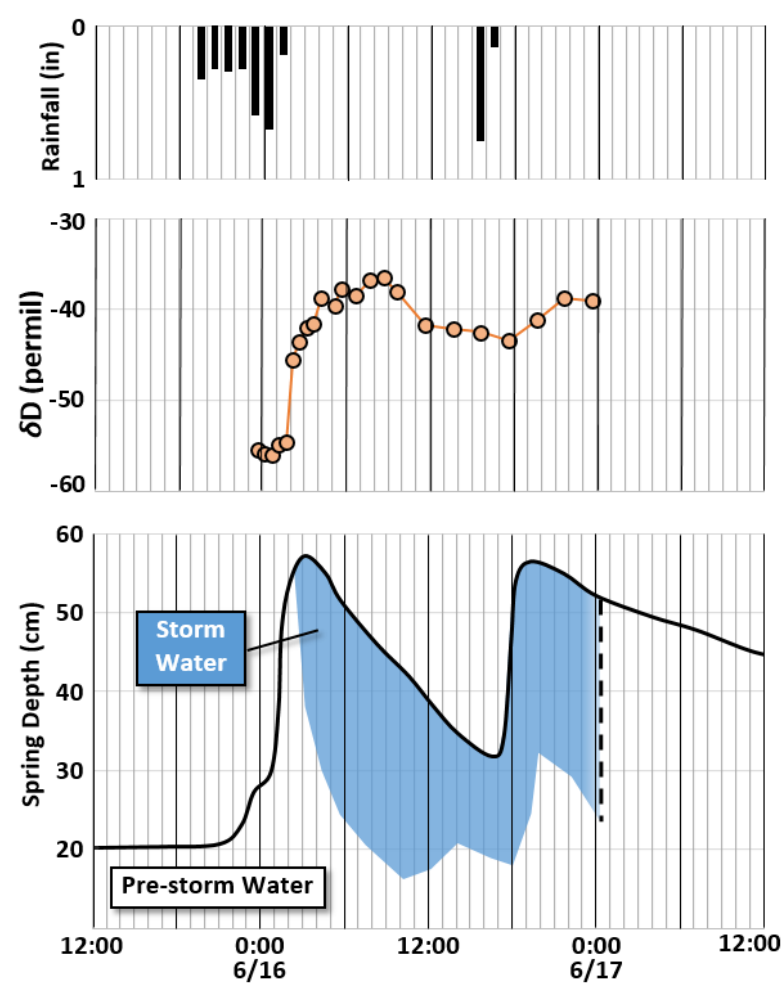

Figure 10. Tippery Spring, June (3-inch) Storm, rainfall, $\delta D$ values, and spring hydrograph with pre-storm and storm water separation. Vertical dashed line indicates end of sampling. Vertical grid has a one-hour minor interval and six-hour major interval.

timing and scale of these changes reflected the distinct behavior of the two springs and the two storm events.

\section{May (1-inch) Storm Ions and Turbidity}

Tippery Spring's ion chemistry and turbidity reflect the influence of storm recharge in relation to water level (Figure 12). TDS and alkalinity showed a similar trend. Initially during the rising limb, little change was seen in TDS. Just before peak flow, a spike in values occurred followed by a rapid decrease in concentration, and a plateau at a lower concentration over the falling limb of the hydrograph. This spike occurred at the onset of storm water as indicated by the stable isotopes.

Turbidity also responded to the arrival of surface water, but with a slower recovery than TDS and alkalinity. No turbidity change was observed during the rising limb, with the first increase occurring at the onset of the storm water signal near peak flow. Turbidity then rose sharply, reaching peak turbidity 3 hours after peak flow before gradually returning to baseflow turbidity by the end of sampling. 

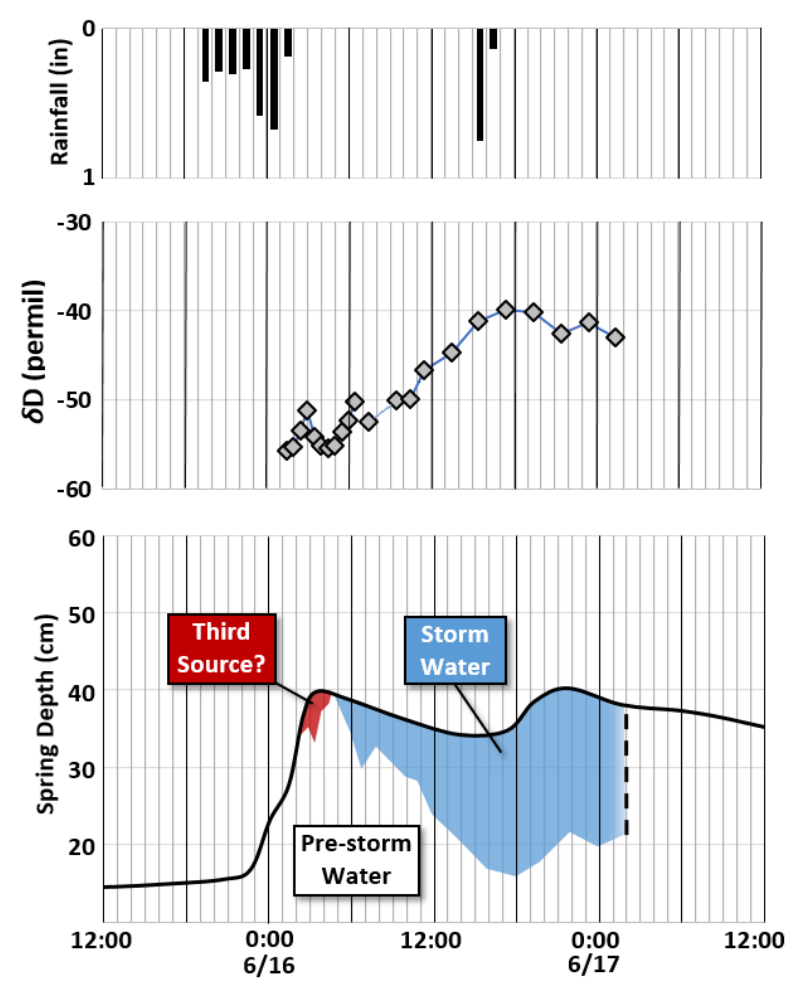

Figure 11. Near Tippery Spring, June (3inch) Storm, rainfall, $\delta D$ values, and spring hydrograph with pre-storm and storm water separation. Vertical dashed line indicates end of sampling. Vertical grid has a one-hour minor interval and six-hour major interval.

Near Tippery Spring's ion chemistry and turbidity response to the May storm highlights differences between how these two springs behave, most notably the initial response and the relation of values to peak flow. Similar to Tippery Spring, Near Tippery Spring showed little change during the gradual rising limb. The first changes occurred around peak flow and the onset of a mixed water source as indicated from the isotopes (Figure 13). Unlike Tippery Spring, this first mixed water source corresponded to a decrease in TDS, alkalinity, and turbidity, which lasted for several hours. As this source then gave way to the storm water signal, TDS and alkalinity values not only recovered, but increased beyond pre-storm values, reaching peak concentration 6 hours after peak flow. Turbidity also recovered and increased beyond pre-storm values, reaching peak turbidity nearly 12 hours after peak flow. TDS, alkalinity, and turbidity then gradually recovered to pre-storm values by the end of sampling.

\section{June (3-inch) Storm lons and Turbidity}

Tippery Spring's response to the June storm showed a similar behavior to the May storm; an initial
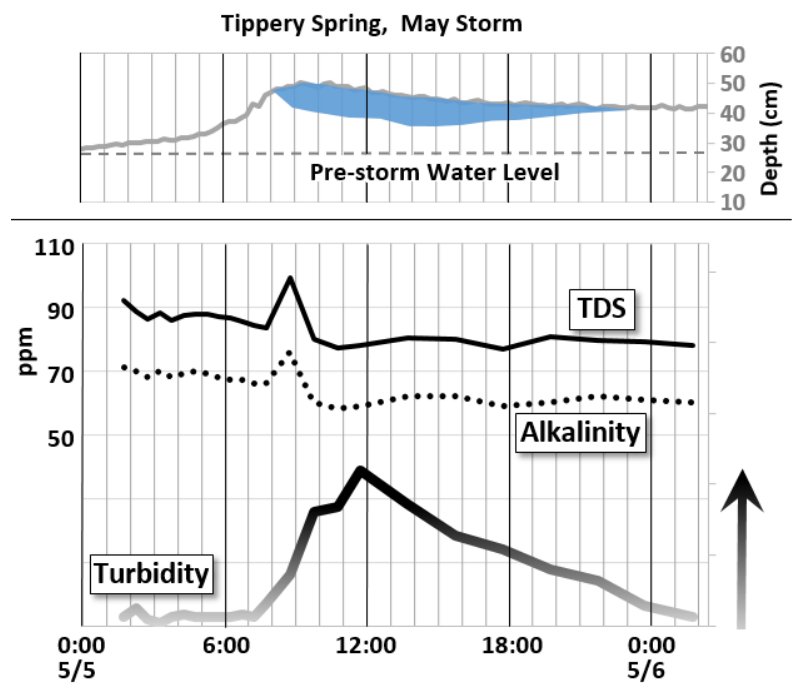

Figure 12. Tippery Spring, May (1-inch) Storm parameters in addition to separated hydrograph: Total dissolved solids (TDS), alkalinity, and turbidity. Turbidity values were determined semi-quantitatively from photographic black and white luminosity values of bottles (Figure 4), with darker bottles having a lower luminosity and higher turbidity as shown by increase in intensity along the graphed line. Vertical grid has a one-hour minor interval and six-hour major interval.

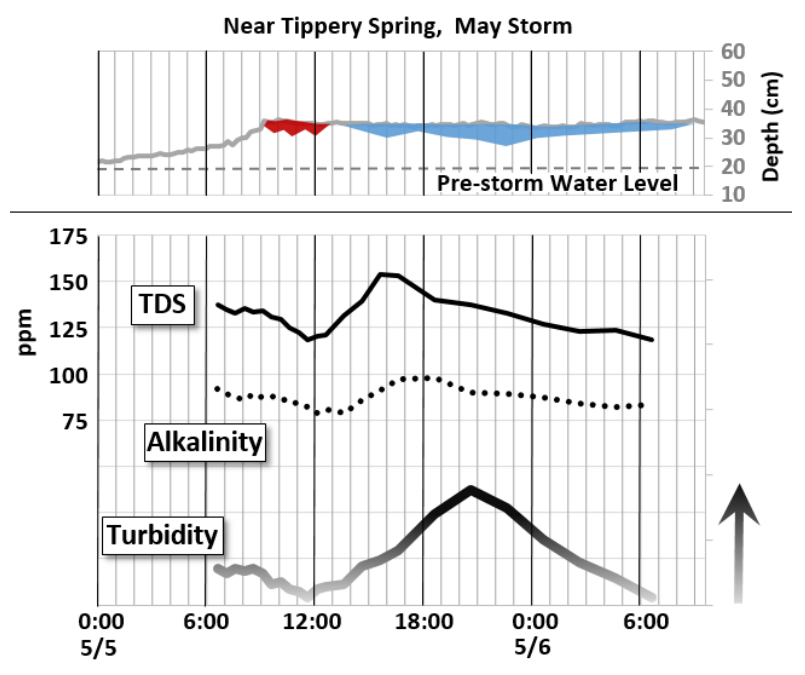

Figure 13. Near Tippery Spring, May (1-inch) Storm additional parameters in relation to rainfall and spring water level: TDS, alkalinity, and turbidity. Vertical grid has a one-hour minor interval and six-hour major interval. 
spike, followed by a decrease in TDS and alkalinity corresponding to the onset of storm water around peak flow (Figure 14). The increase in turbidity again lagged behind the TDS peak. This pattern repeated during the second storm pulse during the June storm, indicating the behavior occurs irrespective of antecedent conditions.

Although the second storm pulse produced a similar rise in water level compared to the first pulse, it did not produce an equivalent change in TDS, alkalinity, and turbidity. These additional parameters did not return to pre-storm levels by the end of sampling.

Near Tippery Spring's TDS response to the June storm was more complex than the response for the May storm. TDS values fluctuated $\pm 50 \mathrm{ppm}$, while alkalinity values were steady until 5-6 hours after the first indication of storm water. At this point, alkalinity concentration gradually dropped by $60 \mathrm{ppm}$ over 6 hours before returning to pre-storm levels (Figure 15). Although the second storm pulse produced a subsequent water level rise, it did not produce an apparent change in TDS and alkalinity.

Near Tippery Spring's turbidity response during the June storm was also more variable, with several peaks occurring throughout the sampling period. Turbidity initially rose sharply during the rising limb, but then dropped after the onset of the potential third source

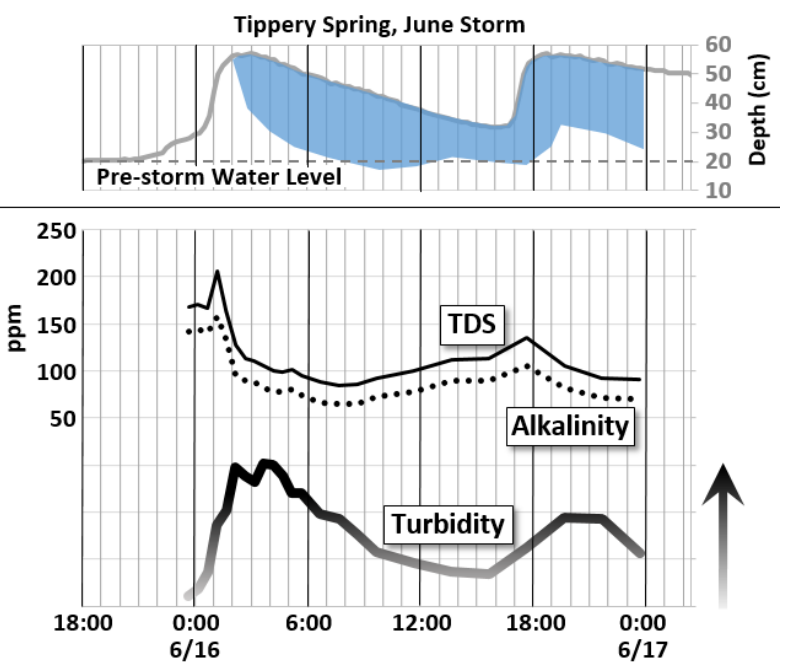

Figure 14. Tippery Spring, June (3-inch) Storm additional parameters in relation to spring hydrograph: TDS, alkalinity, and turbidity. Vertical grid has a one-hour minor interval and six-hour major interval. around peak flow. Turbidity then rose again at the onset of storm water, and gradually decreased throughout the rest of the sampling period. TDS, alkalinity, and turbidity all returned to values similar to the pre-storm values by the end of sampling.

\section{Discussion}

Water level change, stable isotope chemistry, ion chemistry, and turbidity were all affected by storm intensity. Antecedent conditions prior to each storm also affected initial concentrations and water levels. The recharge style of each spring, first noted from prior research, was further described through high-resolution water sampling.

\section{Effect of Antecedent Conditions, Storm Intensity, and Spring Recharge Style on Spring Response Antecedent Conditions}

For the May storm, antecedent conditions at both springs were marked by elevated water levels and decreased ion and alkalinity concentrations due to the recent rainfall a few days before sampling. For the June storm, antecedent conditions at both springs were marked by lower water levels and increased ion and alkalinity concentrations due to the lack of recent rainfall. Despite the greater rainfall and greater increase in water level during the June storm, water level response began later than for the May storm. This lag was likely due to the soil moisture deficit from dryer antecedent conditions.

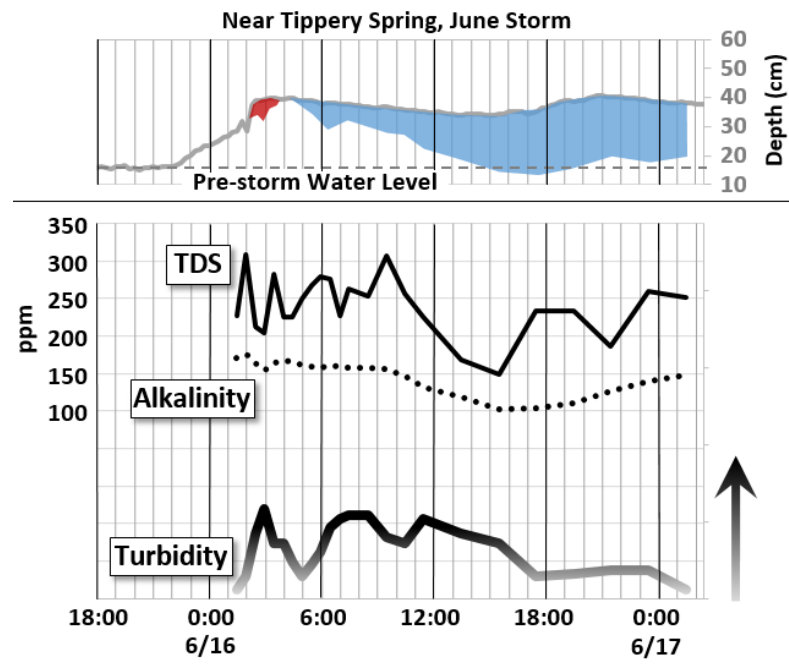

Figure 15. Near Tippery Spring, June (3-inch) Storm additional parameters in relation to rainfall and spring water level: TDS, alkalinity, and turbidity. Vertical grid has a one-hour minor interval and six-hour major interval. 
The ion concentrations also showed variation in response to antecedent conditions. Tippery Spring showed an elevated TDS spike on the rising limb. This spike was higher under the dry initial conditions of the June storm. The higher initial concentration may have occurred because there was less flushing of the system prior to the June storm. The concentrations were more variable at Near Tippery Spring, which may indicate flushing of different sources. The isotope data suggest that the sources varied from the "unknown" third source to dominantly storm water, but the portion of storm water was not as high as observed at Tippery. Thus, the isotope data indicated that the lower contribution of storm water seems to lead to varied TDS at Near Tippery Spring.

Initial stable isotope chemistry did not vary significantly between the two storms for both springs. The similar initial conditions indicated that, despite recent rainfall or lack thereof beforehand, average isotopic composition storm water values prevailed at the springs prior to the storms. This result is not surprising given the samples were collected a month apart, i.e., in the same season.

\section{Storm Intensity}

In response to intensity, the 1-inch May storm produced a smaller water level rise at Tippery Spring and Near Tippery Spring (23 cm and $14 \mathrm{~cm}$, respectively), while the 3-inch June storm produced a greater water level rise at the two springs ( 37 and $26 \mathrm{~cm}$, respectively). This greater overall water level response at both springs from the June storm occurred despite the drier antecedent conditions and moisture deficit, further emphasizing the influence of focused recharge driving fast flow.

The alkalinity and TDS variation decreased with the input of storm water (as indicated by the isotope hydrograph). The decrease is greater when the isotopes indicated a larger portion of storm water. The isotopic mixing indicated a greater storm water component during the June storm and a greater drop in TDS. At Near Tippery Spring, the portion of pre-storm water was lower and the TDS and alkalinity data were more variable.

In general, concentration decreases were also accompanied by an increase in turbidity, signaling the arrival of storm water with high suspended sediment flushed in at sinks. However, the turbidity lagged behind the TDS response. The response lag was shorter by several hours for the high intensity June storm compared to the May storm. The isotopes indicated that the portion of storm water rose faster for the June storm as well, which may explain the more rapid sediment input.

\section{Spring Recharge Style}

Before intensive isotopic analysis of these springs, notable chemical and thermal behavior differences had been observed. Tippery Spring showed lower overall ion concentrations and a flashier water level and temperature response to storms. These characteristics for Tippery were attributed to a more direct connection to surface recharge. For Near Tippery Spring higher overall ion concentrations and a buffered water level and temperature response to storms were observed and attributed to a more diffuse recharge. These springs' behaviors and conceptual models were further described and quantified here through high resolution sampling for stable isotopes and additional parameters and the subsequent hydrograph separation. Due to their close proximity, storm response contrasts between the springs can be attributed to the nature of recharge and flow within each springs capture area, rather than to the timing of the storm itself. Measuring spring responses during storms of different intensities further highlighted these recharge behaviors. Tippery Spring's isotope data supported a conceptual model of a recharge area with a stronger surface connection and well-developed conduit network, while Near Tippery Spring's responses supported a conceptual model with a more diffuse surface connection and less developed conduit network.

\section{Third Source at Near Tippery Spring}

While the assumption of a binary mixing model worked well for Tippery Spring, this was not the case for Near Tippery Spring. A possible third mixing source was hinted at with the variable storm response of some parameters, such as alkalinity and turbidity, and became more apparent during analysis of stable isotope mixing.

At peak flow during both storms, and continuing for several hours past peak flow, isotopic values indicated mixing of a new source before briefly returning to baseflow isotopic values preceding the arrival of the storm water signal. During the May storm, this period had isotopic values which were more depleted (around $-56.0 \%$ oD) than baseflow $(-53.5 \%$ oD). As the storm isotopic value was more enriched than baseflow, this period of mixing with a depleted isotopic source during the May storm could not have been explained as mixing 
of baseflow water with the enriched storm water. Considering the wet antecedent conditions preceding the May storm, it is possible that this third source was perched epikarst water from a colder precipitation event which was then flushed into the flow network in response to recharge from above.

This short-duration mixing signal variation also occurred during the June storm, although isotopic composition showed enrichment instead of depletion. As such, this appeared to be binary mixing of baseflow water with storm water. Considering the observation during the May storm, however, it is still possible that this was also a third source mixing which had a similar isotopic signal to storm water rather than a depleted soil water signal due to dry antecedent conditions.

\section{Conclusions}

High-resolution sampling of stable water isotopes and additional parameters provided evidence to understanding the recharge and flow behavior for two karst springs, Tippery Spring and Near Tippery Spring. As these two springs are adjacent to each other, they experience recharge from the same storm events, and thus have similar pre-storm baseflow isotopic compositions. In response to individual storms, though, their isotopic signatures vary based on storm intensity, but also due to their unique recharge behaviors.

For Tippery Spring, a more rapid recharge through welldefined surface inputs, such as sinks and sinkholes, with rapid transit through a more developed conduit network was supported. For Near Tippery Spring, a more diffuse, buffered recharge behavior through soil and epikarst, with a delayed transit through a less defined conduit network was supported. These behaviors appeared respective of storm intensity, which only varied the degree of response. Comparing the timing of storm water to additional parameters, such as TDS, alkalinity, and turbidity, further supported these conceptual models.

High-resolution monitoring of spring isotopic signatures in response to storms can elucidate how storm water infiltrates and moves within a recharge area. For these two springs, their close proximity further contrasted their unique recharge behaviors. These comparisons produced useful hydrologic information which is important for designing appropriate monitoring programs to provide source water protection in karst.

\section{Acknowledgements}

The authors would like to acknowledge the National Science Foundation's Hydrologic Sciences Program under award number 1417477 . Additional isotopic data were provided by the NSF-supported Shale Hills Susquehanna Critical Zone Observatory. Special thanks to the landowners of the springs and sinkhole who allowed us to access these features.

\section{References}

Berg TM. 1980. Geologic Map of Pennsylvania. Pennsylvania Geological Survey, Harrisburg, PA.

Covington MD, Luhmann AJ, Gabrovsek F, Saar MO, Wicks CM. 2011. Mechanisms of heat exchange between water and rock in karst conduits. Water Resources Research: 47: W10514. https://doi. org/10.1029/2011WR010683.

Duffy C, Thomas E. 2011. CZO Dataset: Shale Hills Stable Isotopes, Precipitation (2008-2011). Retrieved 16 March 2016, from http://criticalzone.org/shalehills/data/dataset/2593/.

Ford DC, Williams PW. 1989. Karst geomorphology and hydrology. London: Chapman \& Hall, 601 p.

Fredrickson GC, Criss RE. 1999. Isotope hydrology and residence times of the unimpounded Meramec River Basin, Missouri. Chemical Geology, 157: 303-317.

Herman EK, Toran L, White WB. 2009. Quantifying the place of karst aquifers in the groundwater to surface water continuum: A time series analysis study of storm behavior in Pennsylvania water resources. Journal of Hydrology 376 (1): 307-317.

Hull LC. 1980. Mechanisms controlling inorganic and isotopic geochemistry of springs in a carbonate terrane [Ph.D. thesis]. The Pennsylvania State University, University Park, PA.

Lakey B, Krothe N. 1996. Stable isotopic variation of storm discharge from a perennial karst spring, Indiana. Water Resources Research. 32 (3): 721-732.

Lee ES, Krothe NC. 2001. A four-component mixing model for water in a karst terrain in south-central Indiana, USA. Using solute concentration and stable isotopes as tracers. Chemical Geology. 179: 129-143.

Luhmann AJ, Covington MD, Peters AJ, Alexander SC, Anger CT, Green JA, Runkel AC, Alexander Jr. EC. 2011. Classification of thermal patterns at karst springs and cave streams. Groundwater. 49 (3): 324-335.

Perrin, J Jeannin P-Y, Zwahlen F. 2003. Epikarst storage in a karst aquifer: a conceptual model based on isotopic data, Milandre test site, Switzerland. Journal of Hydrology 279: 106-124.

Shuster ET, White,WB. 1971. Seasonal fluctuations in the chemistry of limestone springs: a possible means for characterizing carbonate aquifers. Journal of Hydrology 14: 93-128. 
64 NCKRI SYMPOSIUM $7 \quad$ 15TH SINKHOLE CONFERENCE 